\title{
底泥による溶存酸素消費過程における 濃度境界層発達の影響 \\ THE EFFECT OF DEVELOPING DIFFUSIVE BOUNDARY LAYER ON SEDIMENTARY OXYGEN DEMAND
}

\author{
東野 誠1 \\ Makoto HIGASHINO \\ 1正会員 博 (工) 大分工業高等専門学校助教授 土木工学科（于870-0152 大分市大字牧1666）
}

\begin{abstract}
A model of sedimentary oxygen demand (SOD) for a sediment bed for finite length is presented. The model describes the effect of developing a diffusive boundary layer on oxygen transfer just above the sediment/water interface and on microbial oxygen uptake inside the sediment. Variations of biomass profile inside the sediment, dissolved oxygen concentration profile near the sediment/water interface, and SOD in accordance with the developing diffusive boundary layer are investigated numerically.
\end{abstract}

Key Words : dissolved oxygen, sedimentary oxygen demand, sediment/water interface, diffusive boundary layer, oxygen uptake

\section{1.はじめに}

湖沼・貯水池において，水中から底泥表面へと移動す る溶存酸素 (DO) のフラックス (SOD : Sedimentary Oxygen Demand)は，底泥直上の水柱のDO収支に大きな 影響を及ぼす. SODは底泥内部での生物・化学的DO消 費過程のみならず, 底泥直上の水流流速の影響を受けて 変化する.これは, 水・底泥境界面直上の濃度境界層の 厚さが, 流れ場の影響を受けて変化するためである. 従 来よりSODに関する理論的・実験的検討が行われ(1), 2), 3), SODに及ぼす底泥直上の水流流速の影響のモデル化・定 式化等が試みられてきた. これらの定式化・モデル化の 妥当性を検証するために, 実底泥を用いて有限長さの底 泥床による実験が行われている4)，5)，6)．SODのモデル 化・定式化においては，濃度境界層は十分に発達してお り, DO濃度分布の流れ方向の変化はなく, 鈶直方向に のみ変化すると仮定されている．ところが，種々の制約 の下，短い長さの底泥床を用いた実験では濃度境界層が 十分に発達していない場合もあり, そこで得られたデー 夕を用いて上述のモデル化・定式化の妥当性を検証する ことは困難である場合も少なくない.

実験よりSODを求めるには，1）微小電極によって水・ 底泥境界面近傍のDO濃度分布を測定し, 濃度勾配より 算定する，2) 実験系内でのDO収支より算定する，等が
考えられる. まず，1）に関して，微小電極が設置された 場所では，濃度境界層が十分に発達していることが不可 欠である. 次に2)に関して, この方法で得られるSODは 底泥床全長に対する平均值であるが，その際，濃度境界 層の発達段階における局所的なSODの影響を無視するた めに必要な底泥床の長さを知る必要がある。

著者らは, 濃度境界首の発達に伴う局所的な物質移動 フラックス, および有限長さの底泥床全長に対する平均 物質移動フラックスについて検討を行った ${ }^{7)}$. その際, 底泥内部での生物・化学的過程は考慮せず, 水・底泥境 界面での溶質濃度は一定として取り扱った。 ところが, 底泥によるDO消費過程においては底泥表面，および内 部でのDO消費に関与する好気性微生物の分布は，水中 から底泥表面へと移動するDOフラックスの影響, すな わち, 濃度境界層発達に伴うDOフラックス変化の影響 を受けて流れ方向に変化する.

そこで, 本研究では, 底泥内部でのDO消費速度をDO 消費に関与する微生物の菌体増殖速度の関数としてモデ ル化し，これを前述の筆者らの有限長さの底泥床に対す る濃度境界層での物質移動速度に関するモデルと対応さ せて, 有限長さの底泥床に対するSODをモデル化した. 次に, 本モデルによって, 濃度境界層の発達が水・底泥 境界面近傍のDO濃度分布と底泥内部の微生物の菌体濃 度分布に及ぼす影響を調べるとともに, 境界層の発達に 伴うSODの流れ方向への変化について検討した. 


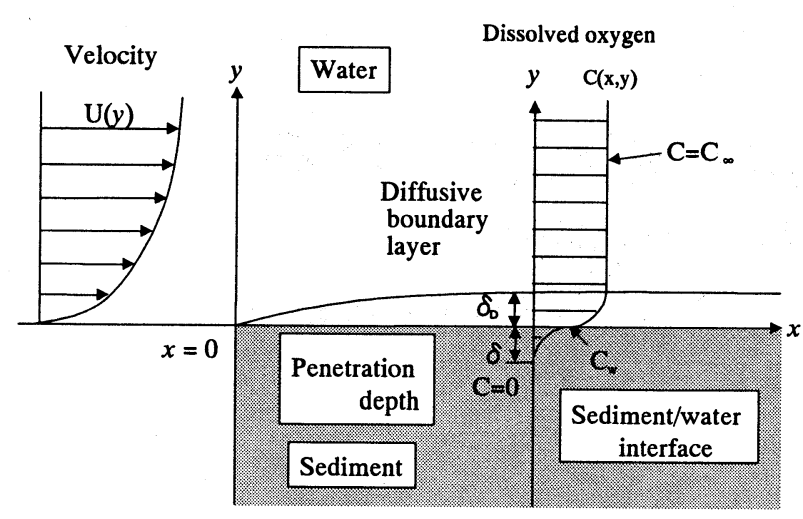

図-1 有限長さの底泥床における水・底泥境界面近傍のDO濃 度分布

\section{2. モデル}

（1）濃度境界層でのDO移動速度，および底泥内部での DO消費速度のモデル化

図一1に示すような有限長さの底泥床に対して考察を行 う. 底泥床前縁 $(x=0)$ において, 乱流場は十分に発達し ている, すなわち, 等流状態であり流速分布の流れ方向 への変化はないと仮定する. 底泥直上の水柱と濃度境界 層内でのDO消費は無視し，DOの移動のみ考慮する．底 泥内部では分子拡散によるDOの移動と, 微生物の菌体 増殖に伴うDO消費を考慮し, 化学的DO消費は考慮しな い. なお, 本研究では底泥内部での好気性従属栄養細菌 の増殖とそれに伴うDO消費を想定している．また，底 泥表面は平坦で水理学的滑面であるとする.

図一1のように，流れ方向に $x$ 軸，鈶值上向きに $y$ 軸を取 る. 濃度境界層は, 底泥床前縁 $(x=0)$ より流れ方向に発 達する. このとき, $x=0$ 以降下流のDO濃度 $C$ の収支は, 次式のように簡略化される.

$$
\frac{\partial C}{\partial t}+U \frac{\partial C}{\partial x}=\frac{\partial}{\partial y}\left\{\left(D_{w}+D_{t}\right) \frac{\partial C}{\partial y}\right\}
$$

ここに, Uは流れ方向の時間平均流速， $D_{w}$ とD はそれぞ れ，DOの分子拡散倸数，および乱流拡散係数である.

底泥内部では，DO以外の物質の収支は考慮せず，微 生物の菌体増殖はDOによってのみ律せられるとする. したがって, 微生物によるDO消費速度は菌体増殖速度 の関数となる. このとき, 底泥内部でのDOの収支は次 式で表わされる.

$$
\frac{\partial C}{\partial t}=D_{s} \frac{\partial^{2} C}{\partial y^{2}}-\frac{1}{Y_{c}} \mu \frac{C}{K o_{2}+C} X
$$

ここに, $X$ は好気性微生物の菌体濃度, $\mu$ は最大DO消費 速度, $\mathrm{Ko}_{2}$ は好気性従属栄養細菌によるDO消費に関する 半飽和定数, $Y_{c}$ は収率, $D_{s}$ は底泥内部でのDOの分子拡 散係数であり, 水中の值の $50 \%\left(D_{s}=1 / 2 D_{w}\right)$ と仮定されて
いる.

一方, 菌体収支はロジステイックモデルを用いて次式 で表わされる.

$$
\frac{d X}{d t}=\left(\mu \frac{C}{K o_{2}+C}-k_{d}\right)\left(1-\frac{X}{X_{\max }}\right) X
$$

ここに, $k_{d}$ は死滅係数, $X_{\text {max }}$ は底泥内部での菌体の飽和 量であり，底泥中に含まれる分解可能な有機物量に関係 する. すなわち，生分解性の有機物を多く含む底泥ほど $X_{\text {max }}$ は大きくなる. この $X_{\text {max }}$ は底泥ごとに異なった值を とる. また，同一底泥においても底泥表面からの深さに よって異なる可能性がある. 実底泥に対する， $X_{\text {max }}$ 值の 推定は容易ではないが，モデル化に際してDO以外の他 の有機物等の収支を考慮する必要がない，等の利点もあ る.

基礎式(1)は，摩擦速度 $U_{*}\left(=\sqrt{\tau_{0} / \rho}\right)$ と動粘性係数 $\nu$ を用いて, 次のように無次元化される. なお， $\tau_{0}$ は底 面せん断応力, $\rho$ は流体(水)の密度である.

$$
\frac{\partial C^{+}}{\partial t^{+}}+U^{+} \frac{\partial C^{+}}{\partial x^{+}}=\frac{\partial}{\partial y^{+}}\left\{\left(\frac{1}{S c}+v_{t}^{+}\right) \frac{\partial C^{+}}{\partial y^{+}}\right\}
$$

上式において，Scは次式で定義されるシュミット数で あり, DOの場合は $20^{\circ} \mathrm{C}$ で500である.

$$
S c=\frac{v}{D}
$$

また, 以下のような無次元量が用いられている.

$$
\left.\begin{array}{l}
C^{+}=\frac{C}{C_{\infty}}, U^{+}=\frac{U}{U_{*}}, v_{t}{ }^{+}=\frac{v_{t}}{v}, \\
y^{+}=\frac{y}{l}, x^{+}=\frac{x}{l}, t^{+}=\frac{U_{*}{ }^{2} t}{v},
\end{array}\right\}
$$

ここに, $C_{\infty}$ は主流中のDO濃度, $\nu_{t}$ は渦動粘性係数であ る. なお, 無次元化に際して, DOの乱流拡散保数 $D_{t}$ は 渦動粘性係数 $\nu_{t}$ と等価である $\left(\nu_{t}=D_{t}\right)$ と仮定されている. また, $l$ は長さスケールであり, 摩擦速度 $U *$ と動粘性係 数レを用いて次式のように表わされる.

$$
l=\frac{v}{U_{*}}
$$

基礎式(2)，（3）も同様に，次のように無次元化される.

$$
\begin{gathered}
\frac{\partial C^{+}}{\partial t^{+}}=\frac{1}{2 S c} \frac{\partial^{2} C^{+}}{\partial y^{+2}}-\mu_{1}^{+} \frac{C^{+}}{K o_{2}^{+}+C^{+}} X^{+} \\
\frac{d X^{+}}{d t^{+}}=\left(\mu_{2}^{+} \frac{C^{+}}{K o_{2}^{+}+C^{+}}-k_{d}^{+}\right)\left(1-\frac{X^{+}}{X_{\max }^{+}}\right) X^{+}
\end{gathered}
$$

上式(8)，（9）において, 次のような無次元量が用いら れている. 

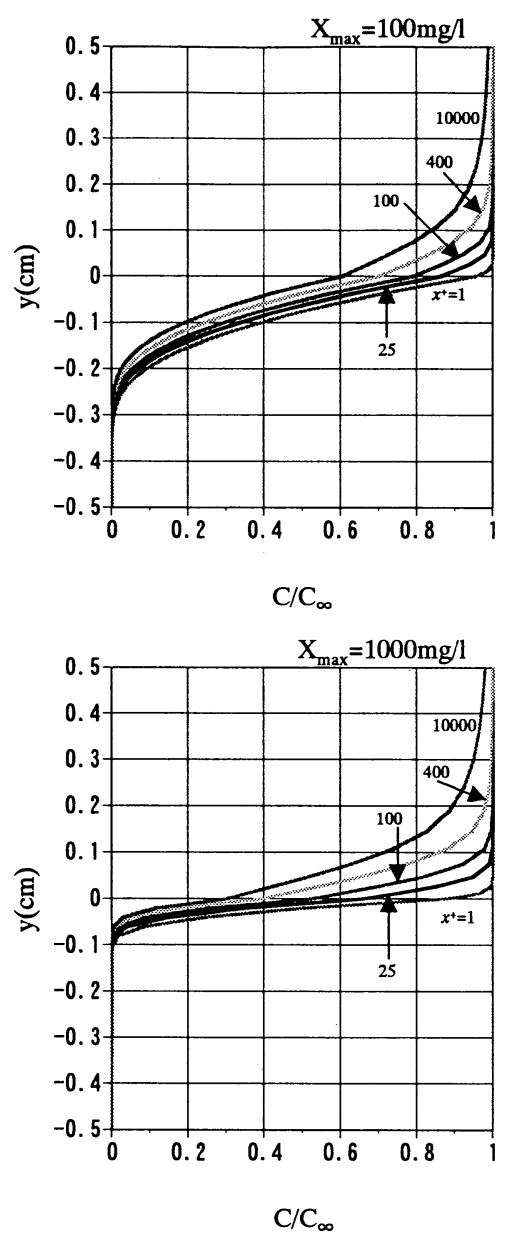

図-2（a） 水・底泥境界面近傍のDO濃 度分布 $(U:=0.1 \mathrm{~cm} / \mathrm{s})$

$$
\left.\begin{array}{l}
X^{+}=\frac{X}{X_{0}}, X_{\max }=\frac{X_{\max }}{X_{0}}, K o_{2}{ }^{+}=\frac{K o_{2}}{C_{\infty}}, \\
\mu_{1}^{+}=\frac{l^{2} X_{0} \mu}{Y_{c} C_{\infty} v}, \mu_{2}{ }^{+}=\frac{l^{2} \mu}{v}, k_{d}{ }^{+}=\frac{l^{2} k_{d}}{v}
\end{array}\right\}
$$

ここに, $X_{0}$ は後述 (2. (2))のように初期菌体濃度である.

\section{（2）SODの数值解とモデル定数}

水・底泥境界面近傍でのDO濃度分布とSODは, 無次 元化した式(4)，（8)，および(9)を数值的に解くことに よって得られる. (4) 式中の渦動粘性係数 $\nu_{t}$ の推定に際 しては, Dadeの式を用いる.これによると, $\nu_{t}^{+}\left(\nu_{t} / \nu\right)$ は粘性底層内 $\left(y^{+} \leqq 10\right)$ と乱流域とで異なった関数形とな り，それぞれ次のように表わされる2).

$$
\begin{gathered}
v_{t}^{+}=\left(n y^{+}\right)^{3} \quad \text { for } \quad y^{+} \leq 10 \\
v_{t}^{+}=\frac{\kappa y^{+}-2+\sqrt{\left(\kappa y^{+}-2\right)^{2}-4}}{2} \text { for } y^{+}>10
\end{gathered}
$$

ここに, $n(=0.1)$ は定数, $\kappa(=0.4)$ はカルマン定数である.
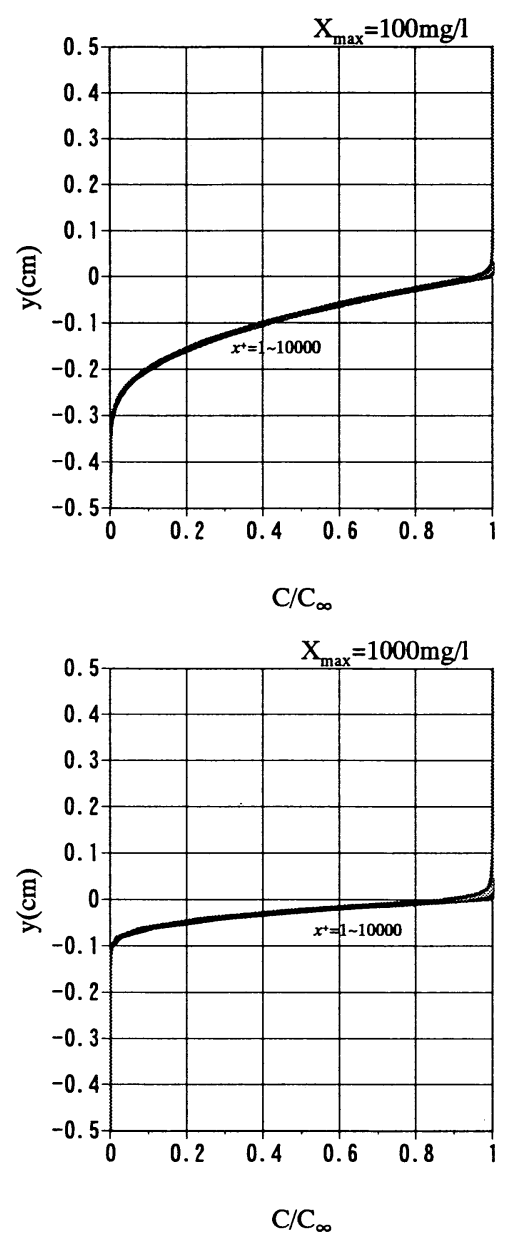

図-2（b）水 - 底泥境界面近傍のDO濃 度分布 $(U *=1.0 \mathrm{~cm} / \mathrm{s})$

また, 底泥直上の流速分布 $U^{+}($式(4)) は, 次式で表わさ れる.

$$
U^{+}=\int_{0}^{y^{+}} \frac{d y^{+}}{1+v_{t}^{+}}
$$

初期条件として, DO濃度は水中の至る所で $C_{\infty}$, 底泥 中では至る所でゼロ，また菌体濃度は底泥中の至る所で $X_{0}$ とした.

境界条件は，水中において

$$
C^{+}=1\left(C=C_{\infty}\right) \text { at } x^{+}=0(x=0) \text { or } y^{+}=300
$$

一方, 水中から底泥表面へと移動したDOは, 底泥表面 から深さ $\delta($ 図-1)の間に消費され，それ以深は無酸素状 態となる. このDOの底泥内部への浸透深さは底泥ごと に異なると考えられるが，本研究では，最近の微小電極 を用いた測定結果 ${ }^{8)}$ に基づいて，底泥内部での境界条件 を以下のように設定した.

$$
C^{+}=0(C=0) \quad \text { at } \quad y=-20 \mathrm{~mm}
$$

数値計算において, 流れ方向 $(x)$ の格子点数は 1000 , 

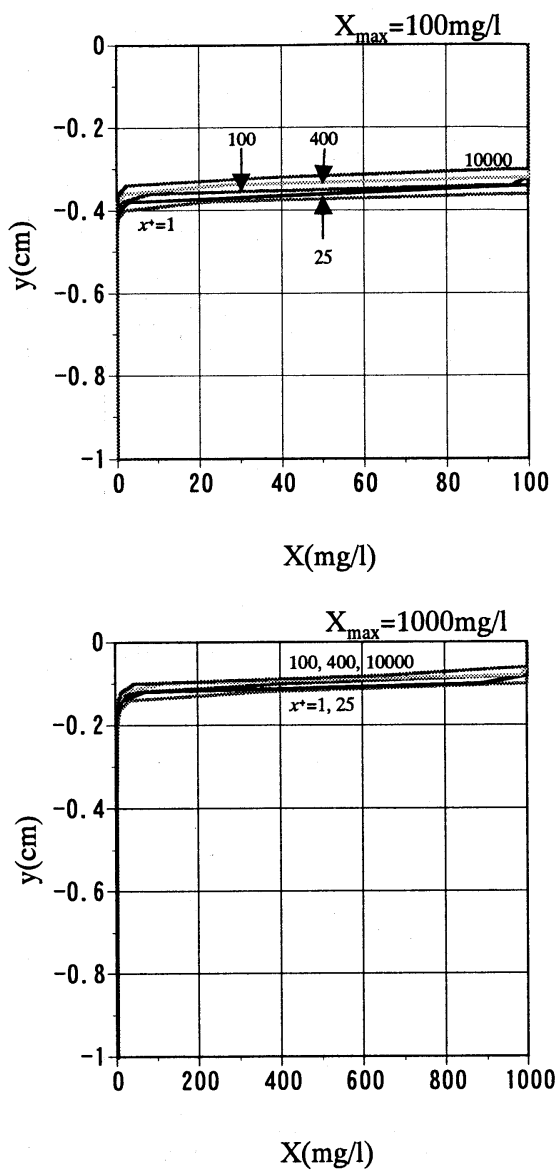

図-3（a） 底泥内部の微生物の菌体濃度分布 $(U *=0.1 \mathrm{~cm} / \mathrm{s})$

鈶直方向 $(y)$ には水中と底泥内部, それぞれ100とした. 濃度境界層の発達がDO濃度分布, 微生物の菌体濃度分 布に及ぼす影響を表現するために, $x$ 方向には底泥床前 縁において間隔が狭くなるよう格子を配置した. また, $y$ 方向では, 乱れの底泥表面への漸近挙動を表現できる よう, 水・底泥境界面近傍において間隔が狭くなるよう 格子を配置してある.

式(4), (8)の両式において, 各時間・各x座標におけ る水・底泥境界面 $(y=0)$ でのDO濃度 $\left(C_{w}\right)$ を与える必要が ある. この $C_{w}$ は界面 $(y=0)$ でのDOフラックスの連続条件 より算定される.

計算は前述の初期状態より, 底泥内部での微生物の菌 体濃度分布が時間とともに変化しなくなるまで繰り返し， 種々の摩擦速度 $U_{*}$ 己 $X_{\text {max }}$ に対する定常状態でのDO濃度 分布, 微生物の菌体濃度分布, およびSODを求めた.

シミュレーションにおいては, 水柱から底泥内部まで, 温度は $20^{\circ} \mathrm{C}$ で一定と考えている. モデル定数は文献值 ${ }^{9}$ を基に決定した. すなわち, 最大DO消費速度定数と死 㓕係数は，それぞれ， $\mu=2.4(1 /$ day $)$, および $k_{d}=0.1(1 / \mathrm{day})$, また, 収率は $Y_{c}=1.0\left(\mathrm{mgX} / \mathrm{mgO}_{2}\right)$ とした. なお，微生物によるDO消費に関する半飽和定数は $K o_{2}=0.2(\mathrm{mg} / l)$, 主流中のDO濃度は $C_{\infty}=10(\mathrm{mg} / \mathrm{l})$ である.
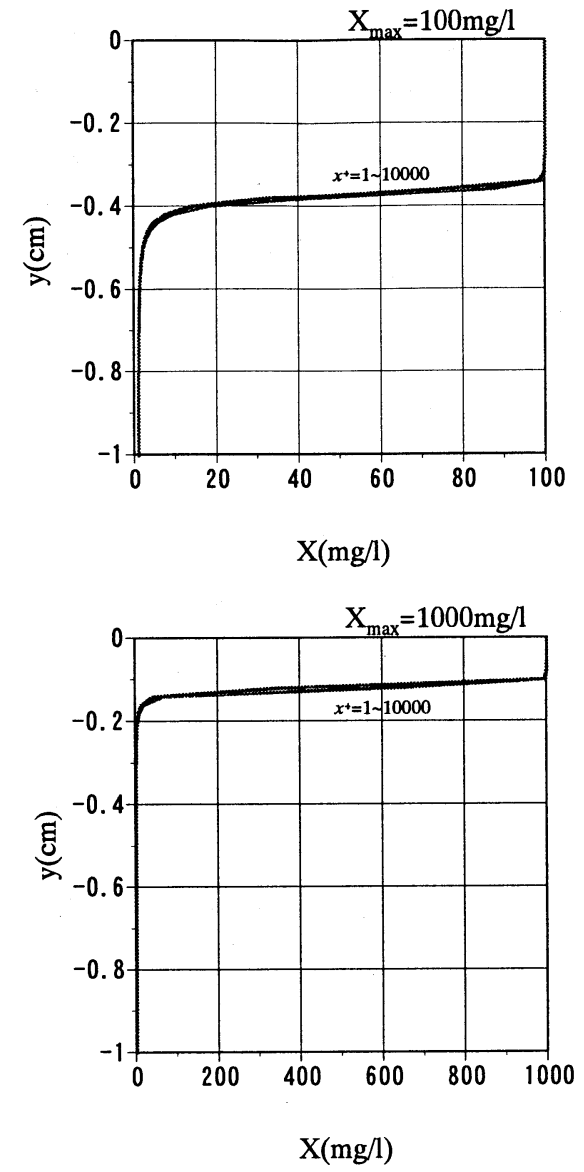

図-3(b) 底泥内部の微生物の菌体濃度分布 $(U *=1.0 \mathrm{~cm} / \mathrm{s})$

\section{DO濃度分布, 微生物の菌体濃度分布, および SOD变化}

\section{（1）水・底泥境界面近傍でのDO濃度分布}

図-2(a)，(b)に，モデルより得られた濃度境界層の発 達に伴う水・底泥境界面近傍でのDO濃度分布の流れ方 向への変化を示す. シミュレーションは, 底泥直上の水 流流速を変化させて(摩擦速度 $U *=0.1,1.0 \mathrm{~cm} / \mathrm{s}), 2 \supset の$ $X_{\text {max }}$ 值 $(100 \mathrm{mg} / l, 1000 \mathrm{mg} / l)$ に対して実施した. なお, シュミット数は $S c=500$ である. これらの図より, 底泥 床前縁 $(x=0)$ からの距離とともに濃度境界層が厚さを増 す(発達する)のは明らかである. 濃度境界層が十分に発 達したとき $\left(x^{+}=10000\right)$, その厚さは $U *=0.1 \mathrm{~cm} / \mathrm{s}$ で約 $1 \mathrm{~cm}$, $U_{*}=1.0 \mathrm{~cm} / \mathrm{s}$ のとき約 $1 \mathrm{~mm}$ であり, 摩擦速度に強く依存す る. 一方, 底泥内部へのDO浸透深さは $X_{\text {max }}$, すなわち, 底泥内部でのDO消費のポテンシャルに強く依存し, 流 れの方向 $(x)$ には $U_{*}=0.1 \mathrm{~cm} / \mathrm{s}, 1 \mathrm{~cm} / \mathrm{s}$ のいずれにおいても 殆んど変化しない．これより，底泥内部へのDOの浸透 深さは微生物によるDO消費活性によって決まり，底泥 直上の水流流速 (摩擦速度) のDO浸透深さへの影響は僅 かであるといえる. 

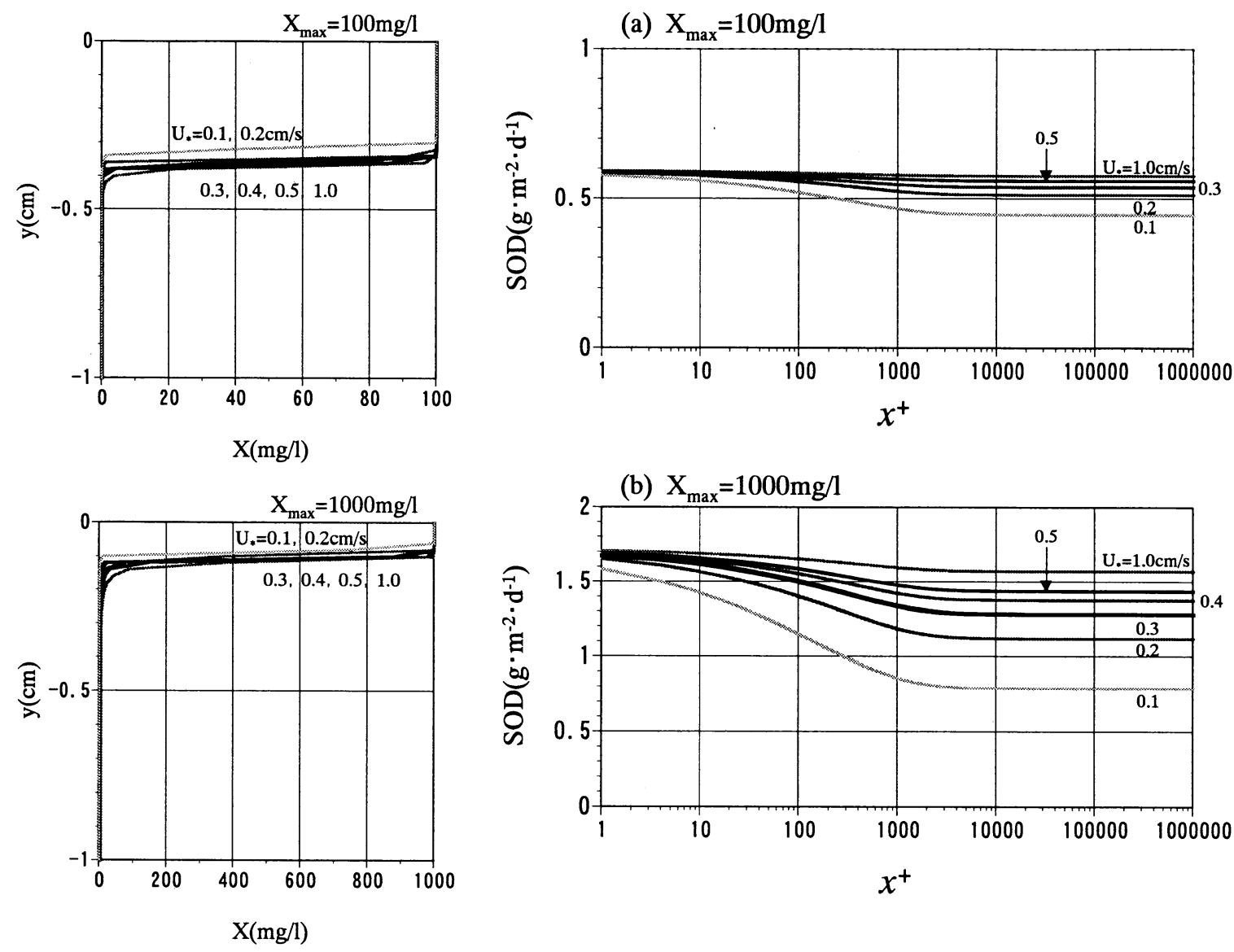

(b) $X_{\max }=1000 \mathrm{mg} / 1$

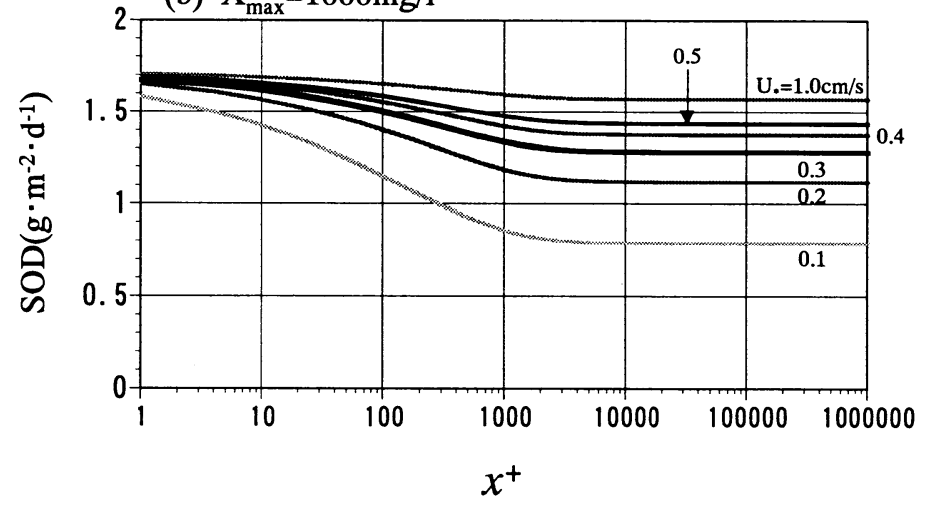

図-3 (c) 底泥内部の微生物の菌体濃度分布

\section{（2）微生物の菌体澧度分布}

モデルによる, 濃度境界層の発達に伴う底泥内部の微 生物の菌体濃度分布の流れ方向への変化を図-3(a), (b) に示す．摩擦速度を $U_{*}=1.0 \mathrm{~cm} / \mathrm{s}$ とした図-3(b)では，流 れ方向 $(x)$ への菌体濃度分布の変化は見られない。これ は, 底泥直上の水流流速が大きければ水中から底泥表面 へのDO移動速度は底泥内部のDO消費速度に対して十分 に大きく, DO濃度分布, 微生物の菌体濃度分布, SOD は底泥床の至る所で底泥内部のDO消費に律せられるこ とに起因している，摩擦速度を小さくした图-3(a) $(U *=$ $0.1 \mathrm{~cm} / \mathrm{s})$ では, 菌体濃度分布は濃度境界層の発達ととも に流れ方向 $(x)$ に変化しており，これは前述 (3. (1))の DO濃度分布と同様の傾向である.

図-3 (c) は, 濃度境界層が十分に発達した状態での菌 体濃度分布を示したものである. 摩擦速度とともに底泥 内部へのDO供給量が増大し, 好気性微生物の分布が底 泥のより深部へと拡大する様子が見て取れる.

\section{(3) SOD}

SODは得られたDO濃度分布より, 次式によって算定 される.

$$
S O D=-\left.D_{w} \cdot \frac{d C}{d y}\right|_{y=0}
$$

(a) $X_{\max }=100 \mathrm{mg} / \mathrm{l}$ 


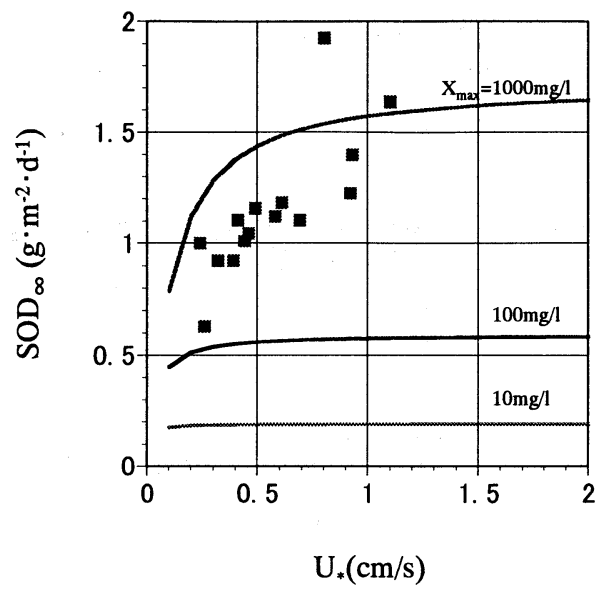

図-5 SOD $\sim$ 䙆係

$X_{\max }=10 \mathrm{mg} / l, 100 \mathrm{mg} / l, 1000 \mathrm{mg} / l$ とし, 摩擦速度U*を変 化させたときのモデルによるSOD 示す. 図にはSteinberger and Hondzoが微小電極によって 測定した実験值(6)併せて示されている．これより，実 験值は $X_{\max }=1000 \mathrm{mg} / l$ とした推定曲線周辺にプロットされ る. 同様に，モデルによる濃度境界層が十分に発達した 状態での水・底泥境界面におけるDO濃度 $\left(C_{w} / C_{\infty}\right)$ の推定 結果を図-6に示す.この図より, Steinberger and Hondzo の実験值は, $X_{\text {max }}=1000 \mathrm{mg} /$ ししした推定曲線よりも下方に プロットされる. Steinberger and Hondzoは実測で得られ た水・底泥境界面近傍でのDO濃度勾配よりSODを算定 している ${ }^{6}$ が，このDO濃度勾配と界面でのDO濃度を精 確に測定することは現時点では困難であり，今後の検討 が必要であろう.

\section{5. 結 論}

本研究で得られた結果を要約すると以下のようである.

1）濃度境界層は, 底泥床前縁 $(x=0)$ より流下とともに 厚くなる. 一方, DO浸透深さは, 流下方向には殆 んど変化しない.これより, 濃度境界層の発達が 底泥内部の微生物活性に及ぼす影響は小さい。

2） SODの流れ方向 $(x)$ の変化は小さく, これより, 濃 度境界層の発達がSODに及ぼす影響は, 摩擦速度 が小さい $(U * \leqq 0.1 \mathrm{~cm} / \mathrm{s})$ 場合を除いて僅かである.

3）濃度境界層は, 摩擦速度と底泥内部での微生物活 性に係わらず, $x^{+}=10000$ において十分に発達し, SODは一定值へと漸近する.

4）SODは底泥内部での微生物活性と底泥直上の水流 流速の影響を受けて変化する.すなわち, 濃度境 界層でのDO移動速度, または底泥内部での微生物 によるDO消費速度のいずれか一方, あるいは両者 によってSODが決まる.

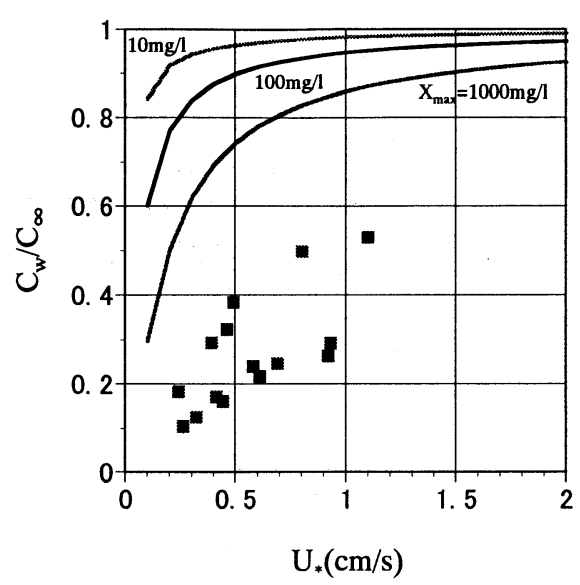

図-6 $\quad C_{w} / C_{\infty} \sim U_{*}$ 関係

謝辞 : 本研究は, 平成14年度文部科学省科学研究費補助 金若手研究(B) (課題番号14750436, 代表 : 東野 誠)の 補助を受けて行われた. また，本研究を遂行するにあた り, ミネソタ大学 ステファン,H.G.教授には熱心にご議 論頂くとともに, 数々の有益なご助言を賜った. ここに, 記して謝意を表する.

\section{参考文献}

1) 中村由行, 御子神 学, H.G.ステファン: 閉鎖性水域に おける底質の酸素消費速度-流れの影響のモデル化-, 海 岸工学論文集, 第40巻, pp.986-990, 1993.

2) Dade,W.B. : Near-bed turbulence and hydrodynamic control of diffusional mass transfer at the sea floor, Limnology and Oceanography, 38(1), pp.52-69, 1993.

3) 細井由彦, 村上仁士, 上月康則 : 底泥による酸素消費に 関する研究，土木学会論文集，No.456/II-21，pp.83-92,1992.

4) Mackenthun, A. and Stefan, H.G. : Effect of flow velocity on sediment oxygen demand: Laboratory measurements, Journal of Environmental Engineering, ASCE, 12(3), pp.222-230, 1998.

5) Josiam, R. and Stefan, H.G. : Effect of flow velocity on sediment oxygen demand: Comparison of theory and experiments, Journal of the American Water Resources Association, 35(2), pp.433-439, 1999.

6) Steinberger, N. and Hondzo, M. : Diffusional mass transfer at the sediment-water interface, Journal of Environmental Engineering, ASCE, pp.192-200, 1999.

7) Higashino, M. and Stefan, H.G. : Diffusive boundary layer development above a sediment/water interface, Water Environment Research, 2003 (印刷中).

8) House,W.A. : Factors influencing the extent and development of the oxic zone in river-bed sediment, Biogeochemistry, 63, pp.317-333, 2002.

9) Rittmann, B.E. and McCarty, P.L. : Environmental Biotechnology: Principles and Applications,McGraw-Hill, 2001.

(2003. 9. 30受付) 